\section{CEO düzenleme odağı, operasyon stratejisi ve KOBİ performansı: Hollanda bahçecilik endüstrisinde bir analiz}

\section{CEO regulatory focus, operations strategy and SME performance: An analysis in the Dutch horticulture industry}

\author{
Nüfer Yasin Ateş ${ }^{1}$ \\ Melek Akın Ateş²
}

${ }^{1}$ Dr. Öğr. Üyesi, Sabancı Üniversitesi, İstanbul, Türkiye, nufer.ates@sabanciuniv.edu

ORCID: 0000-0003-4572-4101 2 Dr. Öğr. Üyesi, Sabancı Üniversitesi,
İstanbul, Türkiye, melek.ates@sabanciuniv.edu

ORCID: 0000-0002-2996-5100

\section{Sorumlu Yazar/Corresponding Author:}

Nüfer Yasin Ateş,

Sabancı Üniversitesi, İstanbul, Türkiye, nufer.ates@sabanciuniv.edu

Başvuru/Submitted: 16/05/2021

Revizyon/Revised: 8/07/2021

Kabul/Accepted: 14/07/2021

Yayın/Online Published: 25/09/2021

Atıf/Citation: Ateş, N.Y., \& Ateş Akın, M., CEO düzenleme odağı, operasyon stratejisi ve KOBİ performansi: Hollanda bahçecilik endüstrisinde bir analiz, bmij (2021) 9 (3): 890-907, doi:

https://doi.org/10.15295/bmij.v9i3.1843
Öz

KOBI'lerin performansı operasyon stratejileri ile yakından ilgilidir. Önceki çalışmalar, CEO özelliklerinin firma stratejileri ve performansı üzerindeki etkilerinin büyük işletmelere kıyasla KOBI’lerde daha fazla olduğunu göstermişlerdir. Düzenleme odağı teorisine göre, CEO kaçınma ve yönelim odağı yöneticilerin temel güdülenme eğilimlerini açıkladığı için önemli bir CEO özelliğidir. $\mathrm{Bu}$ araştırma, operasyon stratejisi, düzenleme odağı ve firma performansı arasındaki ilişkiyi incelemeyi amaçlamaktadır. Araştırmanın örneklemi olarak Hollanda bahçecilik endüstrisine odaklanılmış ve veriler 627 CEO'dan anket yolu ile toplanmıştır. Kümeleme analizi kullanılarak, rekabetçi önceliklere dayalı bir operasyon stratejisi taksonomisi geliștirilmiș ve dört farklı operasyon stratejisi bulunmuştur: "Gelenekçiler", "Mükemmeliyetçiler", "Niş Oyuncular" ve "Odaksızlar". Bulgular göstermektedir ki "Mükemmeliyetçiler" ve "Niş Oyuncular" stratejileri ağırlıklı olarak yönelimci baskın odağa sahip CEO'lar tarafından, "Gelenekçiler" stratejisi ise ağırlıklı olarak kaçınmacı baskın odağa sahip CEO'lar tarafından tercih edilmektedir. "Odaksızlar" stratejisini uygulayan CEO'ların ise baskın bir düzenleme odağı sergilemediği gözlemlenmiştir. Ayrıca, sonuçlar eşsonluluk görüşünü destekleyerek "Odaksızlar" stratejisi dışındaki diğer tüm operasyon stratejilerinin benzer performans ile uygulanabileceğini göstermiştir.

Anahtar Kelimeler: Operasyon Stratejisi, Rekabetçi Öncelikler, Düzenleme Odağı, KOBi Performansı Jel Kodlar1: M11, M12, M19

\begin{abstract}
SME performance is closely related to operations strategies. Prior studies showed that CEO characteristics affect firm strategy and performance more in SMEs than in large organizations. Regulatory focus theory asserts CEO prevention and promotion focus are central CEO characteristics as they explain basic motivational tendencies. This study aims to examine the relationship between operations strategy, regulatory focus and firm performance. By focusing on the Dutch horticulture industry as the study population, data is collected from 627 CEO's using a survey. Using cluster analysis, an operations strategy taxonomy is developed based on competitive priorities and four operations strategies are identified: "Traditionalists", "Perfectionists", "Niche players", and "No focus". The results show that "Perfectionists" and "Niche players" operations strategies are on average adopted by CEOs with a dominant promotion focus, whereas "Traditionalists" operations strategy is on average adopted by CEOs with a dominant prevention focus. On the other hand, it is observed that CEOs implementing a "No focus" operations strategy do not show a dominant regulatory focus. Finally, the results illustrate that all operations strategies except the "No focus" strategy can be implemented with similar performance outcomes, supporting the equifinality view.
\end{abstract}

Keywords: Operations Strategy; Competitive Priorities; Regulatory Focus, SME Performance

Jel Codes: M11, M12, M19 


\section{Extended Abstract}

\section{CEO regulatory focus, operations strategy and SME performance: An analysis in the Dutch horticulture industry}

\section{Literature}

This research examines the associations between CEO dominant regulatory focus, operations strategy adoption and firm performance. The performance of small and medium-sized enterprises (SMEs) is closely related to their operations strategy. Operations strategies are defined as the relative importance firms attach to the competitive priorities of cost, quality, delivery, flexibility and environment. SMEs need to have operations strategies that match their resource base and competencies. In this research, combining the strategy and operations management literature, we investigate the impact of CEO characteristics on operations strategy adoption, specifically regulatory focus (i.e., prevention-focus vs promotion-focus). We formulate the following hypotheses:

Hypothesis 1: CEOs with a dominant prevention regulatory focus adopt operations strategies that emphasize traditional competitive priorities to a greater extent.

Hypothesis 2: CEOs with a dominant promotion regulatory focus adopt operations strategies that emphasize innovative competitive priorities to a greater extent.

Hypothesis 3: There is no meaningful performance difference between SMEs that emphasize innovative competitive priorities and those that emphasize traditional competitive priorities.

This study makes two main contributions to the literature. First, this study contributes to the behavioural strategy field. Behavioural strategy is a sub-field of strategic management, which aims to advance strategic management by improving its foundations based on organizational psychology and sociology theories (Powell, Lovallo, \& Fox, 2011). This study introduces regulatory focus theory from the organizational psychology literature to strategic management and uses this established theory to explain operations strategies and firm performance. Thus, this study extends the behavioural strategy literature by showing the influence of the CEO regulatory focus on the choice of operations strategy. The second contribution of the study is to the operations management field. Current operations management studies have often focused on the structural antecedents of operations strategies (e.g., Vachon, Halley, \& Beaulieu, 2009; Zhao, Yan Yeung, \& Zhou, 2002; Phusavat \& Kanchana, 2007). Although some studies investigate the characteristics of CEOs who have a crucial role in determining operations strategies, these studies mainly focused on the demographic characteristics of CEOs (Kathuria, Porth, \& Joshi, 1999; Kathuria, Partovi, \& Greenhaus, 2010). Studies investigating the personal psychological variables of CEOs and mainly the regulatory focus are pretty limited (e.g., Phadnis, Sheffi, Caplice \& Singh, 2017; Gamache, Neville, Bundy \& Short, 2020). This research contributes to the operations management literature by revealing the behavioural determinants of operations strategies.

\section{Design and method}

By focusing on the Dutch horticulture industry as the study population, we collected data from 627 CEO's via an online survey, using Likert-type scales. We adopt a quantitative approach to test the hypotheses. Measurement reliability and validity are assessed using the Cronbach alpha test and confirmatory factor analysis. The results indicate a good fit of the measurement model. Operations strategy taxonomy based on competitive priorities is developed using cluster analysis by adopting the hierarchical clustering method using the Mahalanobis distance and complete linkage methods. The clusters differ significantly across the five competitive priority dimensions (i.e., cost, quality, delivery, flexibility and environment). Differences between clusters in terms of regulatory focus and firm performance are tested with ANOVA analysis. Figure 1 illustrates the research model.

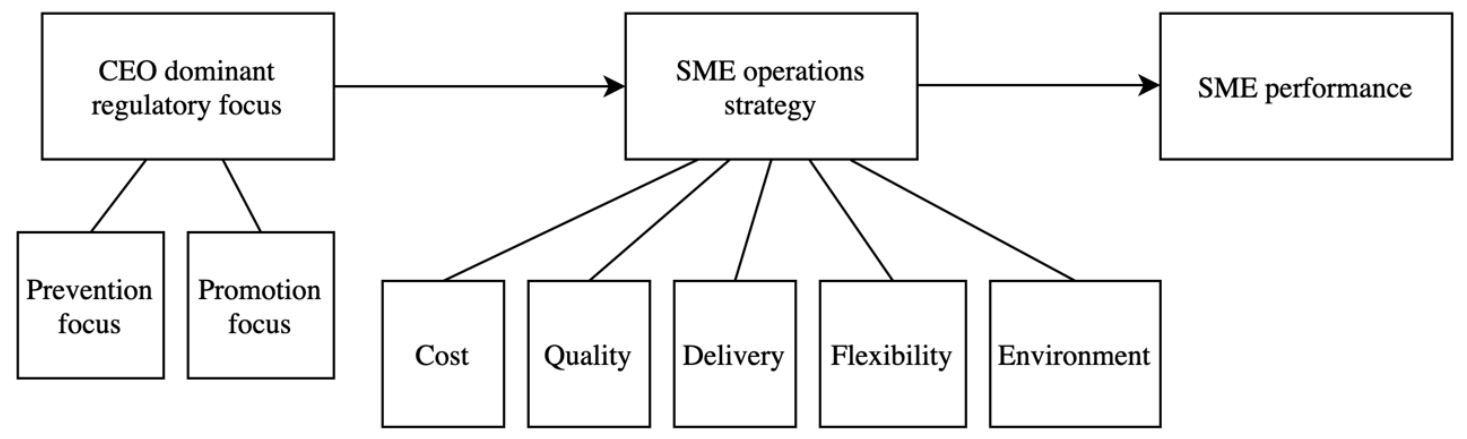

Figure 1: Research Model

\section{Findings and discussion}

Based on the cluster analysis results, we identify four operations strategy clusters, which we label as: "Traditionalists", "Perfectionists", "Niche players", and "No focus". In the "Traditionalists" group, the most emphasized competitive priorities are cost, quality and delivery. Across all clusters, the environment is emphasized the least in this cluster. In the "Perfectionists" cluster, all competitive priorities are significantly emphasized, indicating that firms in this cluster strive for excellence. In the "Niche players" cluster, the most emphasized competitive priorities are quality and environment. Cost priority is only given moderate attention in this cluster. Finally, in the "No focus" strategy, none of the competitive priorities is highly prioritized - all of them are only moderately emphasized. This finding signals that firms in this cluster lack a clear operations strategy.

Comparing the clusters in terms of regulatory focus, we find that the "Perfectionists" and the "Niche players" operations strategies are on average adopted by CEOs with a dominant promotion focus, whereas the "Traditionalists" operations strategy is on average adopted by CEOs with a dominant prevention focus. CEOs implementing a "No focus" operations strategy do not show a dominant regulatory focus. 
Finally, comparing the clusters in firm performance, we find that all operations strategies except the "No focus" strategy can be adopted with similar performance outcomes. These findings support the equifinality view indicating that multiple operations strategies can be equally effective; however, a lack of a strategic orientation results in lower firm performance.

\section{Conclusion, recommendations and limitations}

The findings show that CEOs with a dominant promotion focus choose operational strategies that emphasize more innovative competitive priorities such as environment and flexibility (i.e. 'Niche Players' and 'Perfectionists'). In contrast, CEOs with a dominant prevention focus choose operations strategies that emphasize more traditional priorities such as cost, quality, and delivery (i.e. 'Traditonalists'). On the one hand, a dominant promotion focus of CEOs indicates that they focus on the SMEs they manage to reach their ideal future situations, take risks in this direction and are open to new views. At the same time, they do not hesitate to try multiple ways and mechanisms to achieve success (Wallace, Little, Hill \& Ridge, 2010 ). On the other hand, CEOs with a dominant prevention focus act to understand minimizing losses and protecting the security and prefer operational strategies that emphasize traditional competitive priorities that are more general and usually less risky.

This study has some limitations. First, because the data is cross-sectional, inferences on causality and the directions of relationships cannot be conclusive. Future research may opt for a longitudinal study with data collected over different periods. A second limitation is that statistical controls are sufficient, although the study is conducted with high sample size. Third, it is a limitation that it collects all questions with Likert-type indicators. Finally, future studies can carry out studies that will minimize the risk of common method bias and use different research methods together.

This study also has important managerial implications. First, CEOs must be aware of their regulatory focus that can influence their strategic decisions. Those aware of their dominant regulatory focus may promote people with different regulatory foci to senior management teams. Second, there is no single way for organizations to be successful. Different operations strategies can lead to similar organizational performance. 


\section{Giriş}

Küçük ve Orta Büyüklükteki İşletmelerin (KOBI) performansı, firmaların takip ettikleri operasyon stratejileri ile yakından ilgilidir (Kathuria, 2000). Operasyon stratejileri, firmaların maliyet, kalite, teslimat, esneklik ve çevrecilik rekabetçi önceliklerine verdikleri göreceli önem ile ifade edilir (Boyer ve Lewis, 2002; Ward, McCreery, Ritzman ve Sharma, 1998). KOBI'lerin kendi kaynak tabanlarına ve yetkinliklerine uyan operasyon stratejilerini seçmeleri önemlidir (Peng, Schroeder ve Shah, 2011). KOBI'ler üzerinde yapılan çalışmalarda, CEO özelliklerinin firma stratejileri ve performansı üzerine etkilerinin, büyük işletmelerdeki etkilerinden daha fazla olduğunu bulunmuştur (Lubatkin, Simsek ve Veiga 2006; Raisch ve Birkinshaw, 2008; Wallace, Johnson ve Frazier, 2009). Bunun sebebi, CEO'ların KOBI'lerde daha fazla karar yetkisine sahip olmaları (Finkelstein ve Hambrick, 1990) ve farklı seviyelerdeki çalışan ve yöneticilerle daha sık iletişim içinde bulunmalarıdır (Bierly III ve Daly, 2007; Kammerlander, Burger, Fust ve Fueglistaller, 2015).

$\mathrm{Bu}$ çalışma, CEO düzenleme odağının KOBİ operasyon stratejilerini ve KOBİ performansını nasıl etkilediğini araştırmaktadır. Higgins (1998) tarafından geliştirilen düzenleme odağı teorisi, insanların iki temel bağımsız sistem ile güdülendiğini ileri sürer: (i) kaçınma odağı ve (ii) yönelim odağı. Yönelim odağı yüksek olan kişiler, ideallere ve olabileceklere dayanan arzulanan durumlara odaklanırken (Lanaj, Chang ve Johnson, 2012), kaçınma odağı yüksek olan kişiler ise zorunluluklara ve olması gerekenlere dayanan, olması arzulanmayan durumlara odaklanırlar (Gamache, Neville, Bundy ve Short, 2020). Yönelimci odağı baskın olan kişiler için önemli olan şey başarıları kovalamakken, kaçınmacı odağı baskın olan kişiler için önemli olan şey hatalardan kaçınmaktır (Brockner, Higgins ve Low, 2004). Dolayısıyla yönelim odaklı yöneticiler geleceği kovalanacak fırsatlar olarak görürken, kaçınma odağı olan yöneticiler geleceği kaçınılacak tehditler olarak görme eğilimindedirler (Phadnis, Sheffi, Caplice ve Singh, 2017).

$\mathrm{Bu}$ çalışmanın araştırma sorusu, CEO düzenleme odağının KOBİ operasyon stratejilerine ve bu stratejilerin de KOBİ performansına ne derecede etki ettiğinin belirlenmesidir. Bu soru, Hollanda bahçecilik endüstrisindeki 629 bitki ve çiçek yetiştiricisi KOBİ'den toplanan veriler ile test edilmektedir. Yapılan anket çalışması sonrası, KOBI'lerin operasyon rekabetçi önceliklerine verdikleri önemler üzerinden kümeleme analizi ile, 'Gelenekçiler', 'Mükemmeliyetçiler', 'Niş oyuncular' ve 'Odaksızlar' olarak isimlendirilen dört farklı operasyon stratejisi kümesi elde edilmiştir. Bu kümeler içindeki KOBİlerin CEO'larının baskın düzenleme odağı arasında farklar gözlemlenmiş ve kümeler arasında KOBİ performanslarının farkları incelenmiştir.

Bu çalışma, literatüre iki temel katkıda bulunmaktadır. İlk olarak, davranışsal strateji alanına katkı sunulmaktadır. Davranışsal strateji, stratejik yönetim biliminin organizasyonel psikoloji ve sosyoloji teorileri üzerinde, ayakları yere daha sağlam basan temeller üzerine inşa edilmesini hedefleyen bilim alanıdır (Powell, Lovallo ve Fox, 2011). Bu araştırma, organizasyonel psikoloji literatüründen düzenleme odağı teorisini stratejik yönetim alanına sunmakta ve bu yerleşik teoriyi firma performansını açıklamakta kullanmaktadır. Böylelikle, bu çalışma, davranışsal strateji literatürünü, CEO düzenleme odağının operasyon stratejisi seçimine etkisini göstererek genişletmektedir. Çalışmanın ikinci katkısı operasyon yönetimi alanınadır. Mevcut operasyon yönetimi çalışmaları, operasyon stratejilerinin genellikle yapısal öncülerine odaklanmışlardır (örn., Vachon, Halley ve Beaulieu, 2009; Zhao, Yan Yeung ve Zhou, 2002; Phusavat ve Kanchana, 2007). Stratejilerin belirlenmesinde anahtar bir role sahip olan CEO'ların özellikleri hakkında yapılan bazı çalışmalar olsa da bu çalışmalar çoğunlukla CEO'ların gözlemlenebilir veya demografik özelliklerine yoğunlaşmışlardır (Kathuria, Porth ve Joshi, 1999; Kathuria, Partovi ve Greenhaus, 2010). CEO'ların kişisel psikolojik değişkenlerini ve özellikle düzenleme odağını araştıran çalışmalar ise oldukça sınırlıdır (e.g., Phadnis ve diğerleri, 2017; Gamache ve diğerleri, 2020). Bu araştırma, operasyon yönetimi literatürüne, operasyon stratejilerinin davranışsal öncüllerini ortaya koyarak katkıda bulunmaktadır.

Takip eden bölümde teorik çerçeve açılanmış ve literatür taramasına yer verilmiştir. Bu bölümde araştırma kapsamında incelenecek üç adet hipotez geliştirilmiştir. Sonrasında, çalışma için toplanan veri, ölçekler ve analitik yaklaşımın ele alındığı yöntem bölümününü takiben çalışmanın bulguları sunulmuştur. Çalışma, literatüre yapılan teorik katkılar ve yöneticilere önerilerin aktarıldığı tartışma ve sonuç bölümü ile sonlanmaktadır.

\section{Teorik çerçeve ve literatür taraması}

\section{Operasyon stratejileri ve rekabetçi öncelikler}

Bir firmanın rekabet stratejisi, hangi pazarlarda hangi ürünlerle rekabet edeceğini, her bir ürün pazarındaki uzun dönem hedeflerini ve bu hedeflere ulaşma yollarını tanımlar (Porter, 1997). Rekabet 
stratejisinin temel bileşenlerinden biri operasyon stratejisidir. Operasyon stratejisi, firmanın operasyonlarının firmanın rekabet stratejisini desteklemek için bütünsel olarak nasıl tasarlanacağı ile ilgilenir (Kim ve Arnold, 1996). Operasyon stratejileri, firma operasyonlarında hangi rekabetçi önceliklere ne miktarda önem verileceği ile belirlenir (Carpinetti, Gerolamo ve Dorta, 2000). Rekabetçi öncelikler, firmaların rekabet avantajı kazanmak için takip ettikleri hedefleri nitelendirmektedir (Ward ve diğerleri, 1998). Operasyon stratejisi literatürü, beş temel rekabetçi öncelik belirlemiştir: maliyet, kalite, teslimat, esneklik ve çevrecilik (sürdürülebilirlik) (Christiansen, Berry, Bruun ve Ward, 2003; Miller ve Roth 1994; Kathuria, 2000). Bu alandaki önemli tartışmalardan biri firmaların tek bir rekabet önceliğine mi, yoksa aynı anda birden fazla rekabet önceliğine mi odaklanmalarının gerektiği ile ilgilidir (Boyer ve Lewis, 2002; Hayes ve Wheelwright, 1984). Son zamanlarda yapılan araştırmalar, firmaların rekabetçi öncelikleri tek tek ele almadıklarını ve farklı öneme sahip olan birden fazla rekabetçi önceliğin bir arada uygulandığı operasyon stratejileri olduğunu göstermektedir (Kathuria, Kathuria ve Kathuria, 2018). Bir diğer deyişle, firmaların operasyon stratejileri, benimsedikleri rekabetçi önceliklerin konfigürasyonu (kümeleri) ile ifade edilmektedir (Miller ve Roth, 1994).

Ateş, Wynstra ve van Raaij (2021), Miller ve Roth (1994)'ün alanında öncü çalışmasını takip eden, literatürdeki diğer operasyon stratejisi taksonomilerini incelemiş ve genel geçer altı çeşit operasyon stratejisi tanımlamıştır. Bu stratejilerden ilki, tüm rekabetçi önceliklerin en yüksek derecede benimsendiği ve "Operasyon Mükemmelliği" olarak adlandırılabilecek stratejilerdir (örn: Kathuria, 2000; Martín-Peña, Díaz-Garrido 2008). Bu stratejide farklı rekabetçi öncelikler arasında bir ödün verme ilişkisi olduğu düşünülmez ve tüm önceliklerde mükemmele erişilmek hedeflenir. İkinci operasyon stratejisi ise, ilkinin aksine, hiçbir rekabetçi önceliğin yüksek veya orta düzeyde bile vurgulanmadığ1 'Stratejik Noksanlık' stratejisidir. Bu firmalarda herhangi bir stratejik yönelimin olmadığı göze çarpar (örn. Frohlich ve Dixon 2001; Sum, Low ve Chen, 2004). Ateş ve diğerleri (2021), üçüncü operasyon stratejisini 'Maliyet Odaklılık' olarak adlandırmaktadır. Bu stratejide, maliyet rekabet önceliği diğer rekabetçi önceliklere göre oldukça önemli olarak değerlendirilir (örn: Christiansen ve diğerleri, 2003). Dördüncü operasyon stratejisi, müşterilere hızlı ve güvenilir teslimatın vurgulandığı 'Güvenilir Teslimat' stratejisidir (örn: Christiansen ve diğerleri, 2003; Kathuria, 2000). Beşinci operasyon stratejisinde ise maliyet, kalite ve teslimat rekabetçi öncelikleri birlikte ön plana çıkar (örn: Christiansen ve diğerleri, 2003; Zhao, Sum, Zhang ve Lee, 2006). Ateş ve diğerleri (2021), bu stratejileri "Yalın Yönetim" başlığı altında gruplamıştır Son olarak, "Yenilikçilik" olarak adlandırılan altıncı operasyon stratejisinde kalite ve yenilikçilik rekabetçi önceliklerine yüksek vurgu yapılırken, maliyet önceliği düşük olarak değerlendirilir (örn. Christiansen ve diğerleri, 2003; Frohlich ve Dixon, 2011; Miller ve Roth, 1994).

$\mathrm{Bu}$ altı operasyon stratejisi pek çok ampirik çalışmayla da desteklenmesine rağmen, farklı sektörlerde sektöre özel çevresel bağlam içerisinde yeni operasyon stratejisi konfigürasyonları da gözlemlenebilmektedir.

\section{Üst kademeler kuramı}

Hambrick ve Mason'ın (1984) geliştirdiği 'Üst Kademeler Kuramı', organizasyonların üst düzey yöneticilerin bilişsel çerçevelerinin, değerlerinin ve algılarının, organizasyonların stratejik kararlarını, çıktılarını ve performansını etkilediğini öne sürmektedir. Bu teori, çevreden ve organizasyonun içinden gelen uyaranların, organizasyonların üst kademelerinde görev yapan yöneticilerin bilişsel kapasiteleri ve değerleri ile filtrelendikten sonra onların sınırlı görüş alanlarına girdiğini savunur. Sonrasında üst düzey yöneticilerin seçici algısı ile belirlenen uyaranların bir alt kümesi, yöneticiler tarafından yorumlanır ve yönetsel bir algı oluşur. Bu yönetsel algı ve yöneticilerin değerleri, stratejik kararların belirlenmesinde rol oynar (Hambrick ve Mason 1984). Şekil 1 sınırlı rasyonellik koşulları altında stratejik kararların nasıl verildiğini gösteren bu modeli göstermektedir.

Üst kademeler kuramı, yukarıdaki model kapsamında, stratejik kararları ve organizasyon performansını etkileyen yöneticilerin bilişsel çerçevelerinin, değerlerinin ve algılarının yöneticilerin gözlemlenebilir özellikleri ile ölçümlenebileceğini ileri sürmektedir (Carpenter, Geletkanycz ve Sanders, 2004; Hambrick, 2007). Organizasyonlardaki en üst düzey yöneticiler olan CEO'lar bu kurama göre organizasyonların kararlarında ve performanslarında en etkili aktörlerdir (Hambrick ve Fukutomi, 1991). CEO'lar en anahtar karar verici pozisyonunda oldukları için CEO özelliklerinin organizasyon stratejiler, çıktılar ve kurumsal performans üzerinde önemli etkisi vardır (Cannella, Park ve Lee, 2008). Bu sava dayanarak, pek çok farklı disiplinden araştırmacı CEO'ların demografik art yetişimleri, kişilikleri ve tutumları gibi özelliklerinin kurumsal performansı nasıl etkilediğini incelemiştir (örn. Brockner, Higgins ve Low, 2004; Wiklund, Davidsson ve Delmar, 2003).

Bu konudaki ampirik çalışmaların çoğu büyük firmalarda yapılmış olsa da CEO özelliklerinin etkisinin KOBİlerde daha fazla olacağı yönünde çalışmalar vardır (Lubatkin, Simsek ve Veiga, 2006; Wallace, 
Little, Hill ve Ridge, 2010). CEO özellikleri KOBİ'lerde daha etkilidir, çünkü CEO'ların yönetsel kararlar alma yetisi bu firmalarda daha fazladır (Finkelstein ve Hambrick, 1990). CEO'lar KOBI'lerde büyük ölçekli işletmelere kıyasla daha fazla çalışanla ve farklı seviyelerdeki yöneticilerle iletişim içindedirler (Bierly III ve Daly, 2007; Kammerlander ve diğerleri, 2015). CEO'ların etkisinin KOBİlerde daha fazla olmasına ve KOBI'lerin ülkelerin ekonomik büyümesinde ve teknolojik ilerlemesinde çok merkezi bir rol oynamalarına rağmen, akademik literatürün verilerinin çoğunlukla halihazırda mevcut veri tabanlarından erişilebilen büyük firmalar üzerine olması şaşırtıcıdır (Sum, Low ve Chen, 2004).

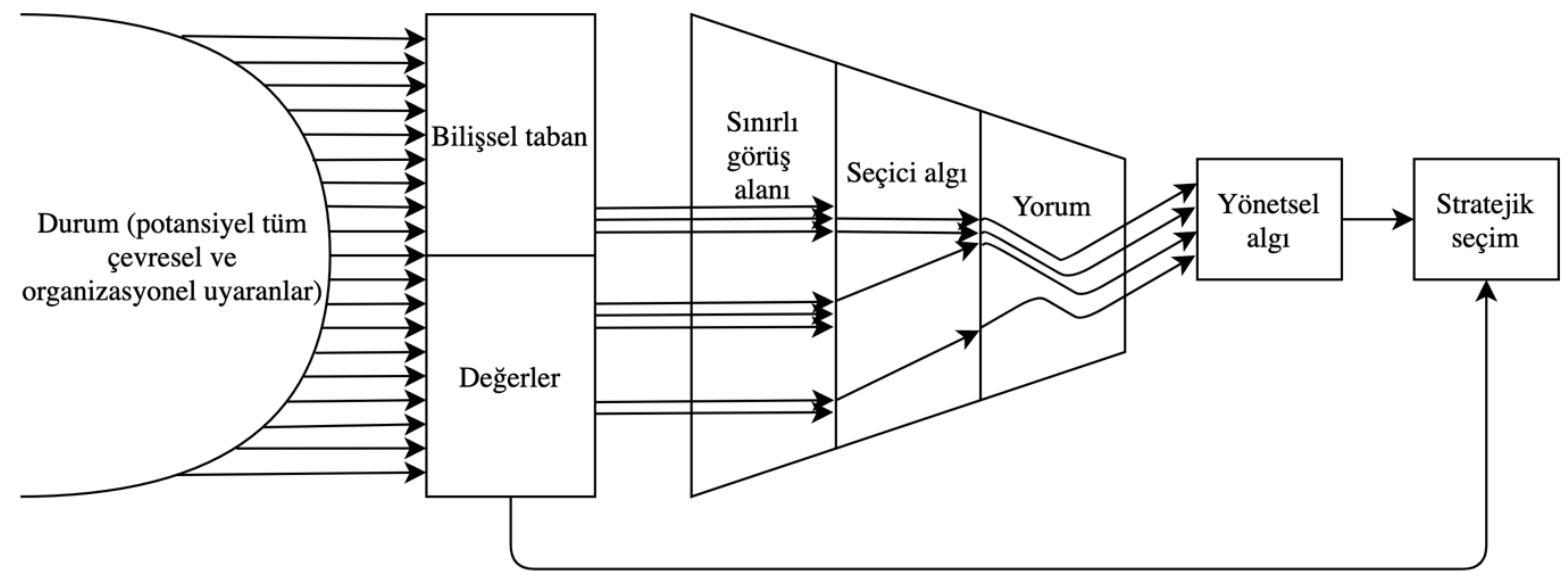

Şekil 1: Kısıtlı Rasyonellik Koşulları Altında Stratejik Seçim

Kaynak: Hambrick ve Mason, (1984: 195).

Literatürdeki bir diğer önemli eksiklik ise, mevcut çalışmaların yoğunlukla CEO ve diğer üst yöneticilerin gözlemlenebilir demografik değişkenlerine odaklanmalarıdır. Bu verilerin daha kolay toplanabilmesi ve önemli bir kısmının mevcut veri tabanlarında hâlihazırda erişime açık olması bu tarz çalışmaların sayısının artmasında önemli bir rol oynamıştır. Ancak, üst kademeler teorisinin temel savı olan, üst düzey yöneticilerin organizasyonel çıktıları etkileyen bilişsel çerçeveleri, değerleri ve algılarının bu gözlemlenebilen değişkenler tarafından ne derecede temsil edilebildiği önemli bir sorudur. Bu sorudan yola çıkarak pek çok araştırmacı üst yöneticilerin demografik karakterlerinin ötesinde, bu yöneticilerin kişiliği, kibiri, narsisizmi gibi çok çeşitli psikolojik değişkenlere de odaklanmışlardır (Zhu ve Chen, 2015; Tang, Mack ve Chen, 2018; Nadkarni ve Herrmann, 2010). Bu çalışmalar içerisinde, özellikle CEO düzenleme odağı hakkında yapılan araştırmaların (örn. Brockner, Higgins ve Low, 2004; Hmieleski ve Baron, 2008; Tumasjan ve Braun, 2012), CEO düzenleme odağının organizasyon stratejilerine ve stratejik kararlarına etki eden önemli bir davranışsal etmen olduğunu bulması dikkat çekicidir (Kammerlander ve diğerleri, 2015; Gamache, McNamara, Mannor ve Johnson, 2015; Kashmiri, Gala ve Nicol, 2019). Bu nedenle, bu çalışmada KOBİ'lerde büyük ölçekli işletmelere göre daha fazla etkisi olması beklenen CEO'ların düzenleme odağının organizasyonun operasyon stratejilerine de etkisinin olacağı öngörülmektedir. Bir sonraki bölümde, düzenleme odağ sunulduktan sonra, CEO düzenleme odağı ve operasyon stratejileri arasındaki ilişki açıklanmıştır.

\section{CEO düzenleme odağı ve operasyon stratejisi}

Düzenleme odağı teorisi (Higgins, 1997; Higgins, Friedman, Harlow, Idson, Ayduk ve Taylor, 2001) bireylerin hedeflerine erişmek için güttükleri motivasyonlardaki farklılıklarını açıklamayı amaçlar. Kronik düzenleme odağı (Higgins, 1997) oldukça sabit olan, çoğunlukla çocukluk ve ergenlik dönemindeki deneyimlerle gelişen bir kişilik özelliğidir (Higgins ve Silberman, 1998). Düzenleme odağının iki temel bileşeni vardır: yönelim odağı (ing. 'promotion focus') ve kaçınma odağı (ing. 'prevention focus'). Yönelim odağı yüksek olan bireyler, ilerleme ve büyüme ihtiyaçları ile güdülenirler. Dolayısıyla olası kazançlarını ve başarılarını en yüksek mertebeye getirmeye odaklanırlar (Crowe ve Higgins, 1997). Bu bireyler eforlarını olumlu çıktılara ve ödüllere erişmek için yoğunlaştırırlar. Başarıya ulaşamama bu bireyleri hayal kırıklığına uğratır ve motivasyonlarını düşürür (Idson, Liberman ve Higgins, 2000). Kaçınma odağı yüksek olan bireyler ise, güvenlik ve emniyet ihtiyaçları ile güdülenirler. Dolayısıyla herhangi bir olumsuz sonuç doğurabilecek hatalardan uzak durmaya odaklanırlar (Brockner, Higgins ve Low, 2004). Hatalarından dolayı cezalandırılma korkusu davranışlarını yönlendirir. Hataların olmaması bu bireylerde olumlu duygulara ve sakinliğe yol açarken, hatalardan kaçınamama gerilim ve olumsuz duygulara neden olur (Idson, Liberman ve Higgins, 2000). 
Düzenleme odağı teorisine göre, kaçınma ve yönelim odağı bireylerin istenen sonuçlara erişmelerinde gösterdikleri stratejik bir eğilimdir (Higgins, 1997). Yani bireyler öz benliklerini düzenlerken, istenen sonuçlara ulaşmayı ve istenmeyen sonuçlardan kaçınmayı yönlendiren bilişsel süreçler ile güdülenirler. Her iki düzenleme odağı aynı hedeflere başarılı bir şekilde erişim için farklı yollar izler. Yönelim odağı yüksek olan bireyler hedeflere erişme sürecinde kazanımları ve büyümeyi önceliklendirirken, kaçınma odağı yüksek olan bireyler ise hedeflere erişme sürecinde hataları azaltmayı ve güvenliği önceliklendirirler (Brockner, Higgins ve Low, 2004; Idson, Liberman ve Higgins, 2000).

Bu iki düzenleme odağı teorik olarak bireylerde bağımsız olarak bulunabilmekte ve davranışları ayrı ayrı etkileyebilmekteyken, ampirik çalışmalar göstermiştir ki her bireyin bir de 'baskın' düzenleme odağı vardır (Shah ve Higgins 2001). Baskın düzenleme odağı baskın olmayan diğer odağın etkisini azaltır ve bireylerin davranışlarının genel olarak tek bir düzenleme odağı tarafından güdülenmesini sağlar (Lockwood, Jordan ve Kunda, 2002). Bireyin yönelim ve kaçınma odaklarının ayrı ayrı davranışlara etkisi olmasına rağmen, baskın olan odak bireyin davranışlarının geneline yansır (De Vries, Koster ve Stam, 2016).

Bu çalışmada, üst kademeler teorisi ve baskın düzenleme odağı görüşüne dayanarak, CEO düzenleme odağının KOBİ operasyon stratejileri ile ilgili olduğu ileri sürülmektedir. Kaçınma odağı baskın olan CEO'lar hedeflerin erişilmemesine karşı çok hassastırlar ve (Higgins 1997) ve kayıpların olmadığı daha güvenli seçeneklere eğilimlidirler (Wallace ve diğerleri, 2010). Baskın düzenleme odağı kaçınma olan CEO'lar, stratejik kararlarını verirlerken, daha temkinli olur, sistematik karar metotları kullanır ve tüm stratejik alternatifleri kapsamlı olarak değerlendirme eğilimi gösterirler (Fredrickson ve Mitchell 1984). Baskın düzenleme odağının kaçınma olması, CEO'ların geleneksel ve muhafazakâr davranmalarına, güvenlik ve koruma ihtiyaçları nedeniyle belirsizlikten kaynaklanan çevresel tehditlerden uzak durmalarına ve firmalarını olmaması gereken durumlara sokmamaya yoğunlaşmalarına neden olur. $\mathrm{Bu}$ nedenlerle, baskın kaçınma odağı olan CEO'lar operasyon strateji seçimlerinde daha geleneksel rekabet önceliklerine (ör. maliyet, kalite, teslimat) vurgu yapan stratejileri seçeceklerdir.

Hipotez 1: Baskın düzenleme odağı kaçınma olan CEO'lar daha geleneksel rekabet önceliklerine vurgu yapan operasyon stratejileri benimserler.

Baskın düzenleme odağı yönelim olan CEO'lar ise başarılarını eksiltecek hataları yapmamaya özen gösterirler. Sadece hedeflerine ulaşmanın ötesinde olumlu çıtılları ve edinimleri en üst düzeye çıkarmaya yoğunlaşırlar (Higgins, 2000). Arzu edilen başarıyı yakalamak için, çoğu zaman farklı düşüncelere ve görüşlere açıktırlar. Kendilerine başarı sunacak farklı yolları ve mekanizmaları sıklıkla benimserler (Brockner, Higgins ve Low, 2004). Yaratıcı düşünmeye ve stratejik kararlarda risk almaya daha açık olan, baskın yönelim odaklı CEO'lar, bu nedenlerle operasyon stratejilerini daha yenilikçi rekabet önceliklerine (ör. esneklik, sürdürülebilirlik) vurgu yapan stratejiler olarak belirleyeceklerdir.

Hipotez 2: Baskın düzenleme odağı yönelim olan CEO'lar daha yenilikçi rekabet önceliklerine vurgu yapan operasyon stratejileri benimserler.

Son olarak, çalışmanın araştırma sorusu kapsamında, KOBİ operasyon stratejileri ile firma performansı arasındaki ilişki hakkında bir hipotez öne sürülmektedir. Operasyon stratejisi ile firma performansı arasındaki ilişkiyi inceleyen literatür en yüksek firma performansını sağlayan tek bir strateji olmadığını, bir diğer deyişle pek çok farklı operasyonel önceliklendirmenin benzer şekilde yüksek performans ile sonuçlanabileceğini bildirmektedir (Boyer ve Lewis, 2002; Gelhard, von Delft ve Gudergan, 2017). Bu görüş, eşsonluluk (equifinality) olarak da nitelendirilmektedir (Marlin, Ketchen ve Lamont, 2007). Bu görüş doğrultusunda, KOBİler için de hem geleneksel hem de yenilikçi rekabet önceliklerine vurgu yapan operasyon stratejilerinin benzer performans sonuçları üreteceği tahmin edilmektedir.

Hipotez 3: Geleneksel veya yenilikçi rekabet önceliklerine vurgu yapan operasyon stratejilerine sahip KOBİ'ler arasinda anlamlı performans farkları beklenmez.

Yukarıdaki hipotezleri ampirik olarak test etmek için, öncelikle incelenen örneklemdeki KOBI'lerin operasyon stratejilerinin konfigürasyonu belirlenecek ve belirlenen operasyon strateji kümeleri arasında CEO'ların baskın düzenleme odağı arasındaki farklar araştırılacaktır. Ek olarak, strateji kümeleri arasındaki olası performans farkları ve CEO düzenleme odağı ile ilişkisi incelenecektir. Geliştirilen teorik çerçeve aşağıda Şekil 2'de gösterilmektedir. 


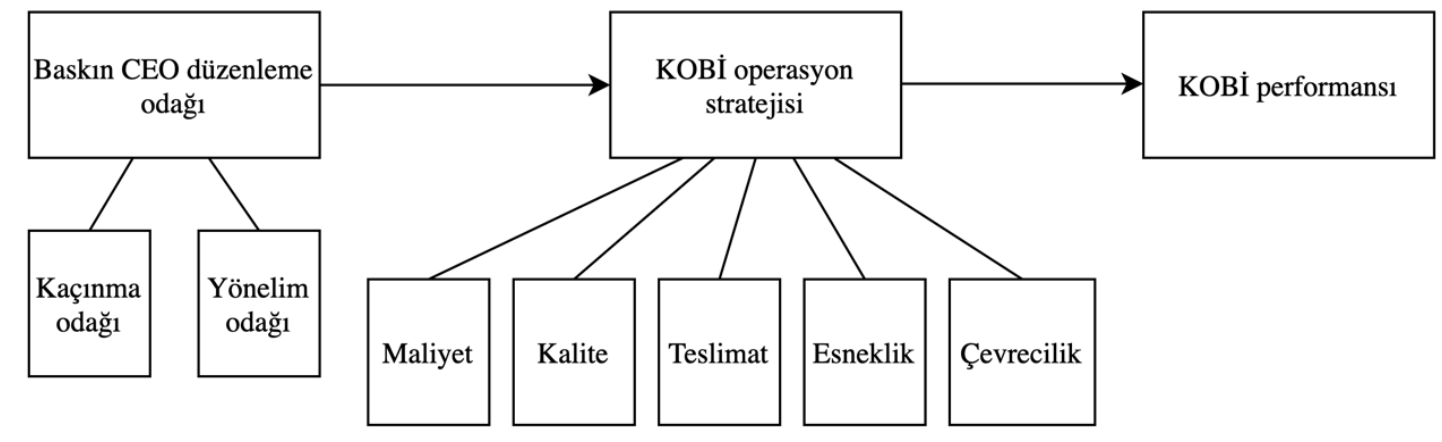

Şekil 2: Teorik Çerçeve

\section{Yöntem}

\section{Veri}

Teorik çerçevede ifade edilen araştırma modelinin ampirik olarak test edilmesi için Hollanda bahçecilik endüstrisinde, çiçek ve bitki yetiştiren KOBI'lerden bir örnekleme anket çalışması uygulanmıştır. Örneklem belirlenirken, yetiştiricilerin bağlı olduğu bir kooperatifin 1004 adet üyesine e-posta ile anket çalışması ulaştırılmış, 865 KOBİ'den cevap alınmıştır. Eksik cevaplı ve CEO dışındaki yöneticiler tarafından cevaplanan anketler dışarıda bırakıldığında, $629 \mathrm{KOBİ}$ den gelen veri bu çalışmada kullanılmıştır. Yüzde altmış iki gibi yüksek bir yanıtlanma oranına erişilmesinde kooperatifin anket çalışmasını desteklemesi ve kooperatife araştırma bulgularının bir rapor olarak teslim edilmesi etkili olmuştur. Cevap veren ve vermeyen firmaların kooperatifte kayıtlı olan verileri (firma yaşı, CEO yaşı, satış hacimleri) arasında yapılan t-testlerinde anlamlı farklar gözlemlenmemiştir; yani örneklem çalışma evrenini temsil etmektedir. Ayrıca erken cevap verenler ile geç cevap verenlerin çalışma değişkenlerinin (CEO düzenleme odağı, performans, firma yaşı, CEO yaşı) t-testleri ile karşılaştırılması da anlamlı farklar ortaya koymamıştır. Geç cevap verenlerin, cevap vermeyenleri daha yakından temsil edebileceği düşünüldüğünde, bu analiz de örneklemin evreni temsil gücünün kuvvetli olduğunu göstermektedir.

Ankete katılan 629 KOBI'nin \%70,1'i sadece çiçek, \%26,6'sı sadece bitki yetiştirmektedir ve ortalama KOBİ yaşı 22,4 yıldır. Örneklemdeki KOBİ'lerin \%58,8'i kendilerini aile şirketi olarak nitelendirmektedirler. Ortalama CEO yaşı 46.2'dir ve erkek CEO'lar örneklemin \%95,4'ünü oluşturmaktadırlar. Tablo 1'de ankete katılan firmaların ve katılımcıların demografik özellikleri belirtilmiştir.

Tablo 1: Ankete Katılan Firmaların ve Katılımcıların Demografik Özellikleri

\begin{tabular}{|c|c|c|c|c|c|}
\hline CEO yaşı & Sayı & $\%$ & Firma yaşı & Sayı & $\%$ \\
\hline 30 yaş altı & 27 & $4.3 \%$ & 10 yaş altı & 86 & $13.7 \%$ \\
\hline $30-39$ & 130 & $20.7 \%$ & $10-19$ & 215 & $34.2 \%$ \\
\hline $40-49$ & 270 & $42.9 \%$ & $20-29$ & 184 & $29.3 \%$ \\
\hline $50-59$ & 160 & $25.4 \%$ & $30-39$ & 85 & $13.5 \%$ \\
\hline 60 yaş ve üstü & 42 & $6.7 \%$ & 40 ve üstü & 59 & $9.4 \%$ \\
\hline CEO cinsiyet & Sayı & $\%$ & Ürün çeşidi & Say1 & $\%$ \\
\hline Erkek & 600 & $95.4 \%$ & Çiçek & 441 & $70.1 \%$ \\
\hline \multirow[t]{2}{*}{ Kadın } & 29 & $4.6 \%$ & Bitki & 167 & $26.6 \%$ \\
\hline & & & İkisi birden & 21 & $3.3 \%$ \\
\hline Aile şirketi & Sayı & $\%$ & & & \\
\hline Evet & 370 & $58.8 \%$ & & & \\
\hline Hayır & 259 & $41.2 \%$ & & & \\
\hline
\end{tabular}

\section{Ölçekler}

Çalışmada kullanılan ölçekler Tablo 2'de gösterilmiştir. Operasyon stratejileri, rekabet önceliklerine verilen önem ile ölçülmüştür. CEO'lara maliyet, kalite, teslimat ve esneklik rekabet önceliklerine ek olarak (Miller ve Roth, 1994; Boyer ve Lewis, 2002), literatürde giderek daha fazla vurgulanmaya başlanan çevrecilik önceliği de sorulmuştur (Martin-Pena ve Diaz-Garrido, 2008). Rekabetçi öncelikler 
ölçekleri, Boyer ve Lewis (2002), Martin-Pena ve Diaz-Garrido (2008), Miller ve Roth (1994) ve Ward ve arkadaşlarının (1998) çalışmalarından alınmıştır ve bahçecilik endüstrine uyarlanmıştır. 5 noktalı Likert ölçeği (1: hiç, 5: çok fazla) ile katılımcılara her bir rekabetçi önceliğin firmaları için ne kadar önemli olduğunu belirtmeleri istenmiştir.

Tablo 2: Ölçekler, Ölçek Güvenilirliği ve Geçerliliği

\begin{tabular}{|c|c|c|}
\hline \multicolumn{2}{|c|}{ Değişkenler ve ölçekler } & Faktör yükü \\
\hline \multicolumn{3}{|c|}{ (1) Maliyet öncelï̆i $(C R=0.72 ; A V E=0.59 ;$ Cronbach alpha $=0.83)$} \\
\hline M1. & Çicek/bitki yetiştirme maliyetlerini azaltmak & 0.645 \\
\hline M2. & Çalışanların üretkenliğini arttırmak & 0.868 \\
\hline M3. & Kapasite verimliliğiini artırıp maliyetleri düşürmek & 0.775 \\
\hline \multicolumn{3}{|c|}{ (2) Kalite önceliği $(C R=0.81 ; A V E=0.67 ;$ Cronbach alpha $=0.85)$} \\
\hline K1. & Kaliteli çiçekler/bitkiler sunmak & 0.847 \\
\hline K2. & En iyi kalite endeksine sahip çiçekler/bitkiler sunmak & 0.773 \\
\hline K3. & Tutarlı ve güvenilir kalite çiçekler/bitkiler sunmak & 0.840 \\
\hline \multicolumn{3}{|c|}{ (3) Teslimat önceliği ( $C R=0.78 ; A V E=0.64 ;$ Cronbach alpha $=0.83)$} \\
\hline T1. & Müşterilere güvenilir teslimat programları sunmak & 0.837 \\
\hline $\mathrm{T} 2$. & Teslimat planlarını başarıyla yerine getirmek & 0.901 \\
\hline T3. & Çiçekleri/bitkileri zamanında teslimata hazırlamak & 0.648 \\
\hline \multicolumn{3}{|c|}{ (4) Esneklik önceliği ( $C R=0.60 ; A V E=0.50 ;$ Cronbach alpha $=0.72)$} \\
\hline E1. & Çok çeşitli çiçekler/bitkiler yetiştirmek & 0.478 \\
\hline E2. & Üretim hacmini talepteki değişikliklere uyarlamak & 0.795 \\
\hline E3. & Üretim kapasitesini kısa sürede etkin bir şekilde uyarlamak & 0.794 \\
\hline \multicolumn{3}{|c|}{ (5) Çevre önceliği ( $C R=0.86 ; A V E=0.73$; Cronbach alpha $=0.89)$} \\
\hline Ç1. & Çevre dostu üretim süreçleri kullanmak & 0.849 \\
\hline Ç2. & Üretim faaliyetlerinizinn çevre üzerindeki etkisini en aza indirmek & 0.888 \\
\hline Ç3. & Şirketinizin olumlu çevresel imajını korumak & 0.824 \\
\hline \multicolumn{3}{|c|}{ (6) Kaçınmacı odak ( $C R=0.71 ; A V E=0.46$; Cronbach alpha $=0.83$ ) } \\
\hline KO1. & İş yerindeki kurallara ve düzenlemelere uymak & 0.529 \\
\hline $\mathrm{KO} 2$. & İşlerimi doğru bir şekilde tamamlamak & 0.689 \\
\hline KO3. & Sorumluluklarımı iş yerinde tamamlamak & 0.726 \\
\hline $\mathrm{KO} 4$. & İş yerindeki görev ve sorumluluklarım & 0.728 \\
\hline KO5. & İş yükümlülüklerimi tamamiyle yerine getirmek & 0.772 \\
\hline KO6. & Görevlerimin detayları & 0.616 \\
\hline \multicolumn{3}{|c|}{ (7) Yönelimci odak ( $C R=0.72 ; A V E=0.48$; Cronbach alpha $=0.84)$} \\
\hline YO1. & İş yerinde çok şey halletmek & 0.708 \\
\hline YO2. & Ne olursa olsun işimi yapmak & 0.689 \\
\hline YO3. & Kısa sürede çok iş yapmak & 0.719 \\
\hline YO4. & İşimde ilerleme kaydetmemi sağlayan faaliyetler & 0.654 \\
\hline YO5. & İş yerindeki performansım & 0.746 \\
\hline YO6. & İş yerinde ne kadar fazla görev tamamlayabileceğim & 0.627 \\
\hline \multicolumn{3}{|c|}{ (8) Firma performanst $(C R=0.69 ; A V E=0.51$; Cronbach alpha $=0.80)$} \\
\hline P1. & Satış artışı & 0.801 \\
\hline P2. & Kâr marjı artışı & 0.757 \\
\hline P3. & Pazar payı artışı & 0.589 \\
\hline P4. & Genel performans artış1 & 0.704 \\
\hline
\end{tabular}

Düzenleme odağı ölçeği için Wallace, Johnson ve Frazier (2009)'un ölçeği kullanılmış ve katılımcılardan iş sırasında ölçekte belirtilen ifadelerdeki düşünce ve faaliyetlere ne sıklıkla odaklandıklarını belirtmeleri talep edilmiştir (1: hiç, 5: çok sık). Düzenleme odağı farklı durumlara göre değişebileceği için (Phadnis ve diğerleri, 2017), ifadeler bahçecilik endüstrisine uyarlanmıştır. Çalışma öncesi kooperatifteki yetiştirici temsilcileri ile pilot çalışma ile anket soruları ön testten geçirilmiştir. Baskın düzenleme odağı değişkeni ise, literatürdeki benzer çalışmalar takip edilerek, katılımcıların ortalama 
yönelimci odak skorlarından ortalama kaçınmacı odak skorları çıarılarak bulunmuştur (Lockwood, Jordan ve Kunda, 2002; De Vries, Koster ve Stam, 2016). Bu ölçeğin yüksek değerleri baskın düzenleme odağının yönelimci, düşük değerleri ise kaçınmacı olduğunu göstermektedir.

Firma performansı ölçeği için ise, Venkatraman ve Ramanujam (1987)'nin çalışmasındaki ölçek kullanılmış ve her bir ifade için katılımcıların firmalarının performansını rakiplerine göre kıyaslaması istenmiştir (1: rakiplerimizden çok daha kötü, 5: rakiplerimizden çok daha iyi).

\section{Ölçek güvenilirliği ve geçerliliği}

R paket programı́nın (versiyon 1.3.959) Lavaan paketi kullanılarak yapılan doğrulayıcı faktör analizi sonucunda uyum iyiliği değerleri $x^{2}=800.01(\mathrm{df}=406, \mathrm{p}<0.001)$, RMSEA $=0.04, \mathrm{CFI}=0.95$, TLI (Tucker-Lewis Index) $=0.95$ ve SRMR $=0.04$ olarak elde edilmiştir (Tablo 2). Gözlemlenen tüm uyum iyiliği değerleri, literatürde kabul edilebilir değerleri üst düzeyde karşılamıştır (Hu ve Bentler, 1998). Tüm değişkenlerin Cronbach alpha değerlerinin $0.7^{\prime}$ den büyük olduğu ve bileşik güvenilirlik değerlerinin de tavsiye edilen eşik değer olan 0.6'dan yüksek olduğu gözlemlenmiştir (Bagozzi, Yi ve Philips, 1991). Ayn zamanda, tüm faktör yükleri kabul edilebilir eşik düzeyi olan 0.4 'ten büyük olduğu için (Anderson ve Gerbing, 1988) yakınsama geçerliliği de sağlanmıştır (Tablo 2). Çıkarılan ortalama varyans (AVE), kaçınmacı odak ve yönelimci odak değişkenleri dışındaki diğer tüm değişkenler için $0.5^{\prime}$ ten daha yüksektir. Kaçınmacı odak ve yönelimci odak AVE değerlerinin eşik değerine çok yakın olduğu ve Crobach alpha ve bileşik güvenlirlik değerlerinin ise eşik değerin altında olduğu göz önünde bulundurularak, görünüş geçerliliğini korumak için herhangi bir ölçüm maddesi ölçeklerden çıkarılmamıştır. Değişkenler arasındaki korelasyonlar Tablo 3'de sunulmuştur. Beş rekabet önceliği, CEO düzenleme odağının iki boyutu ve firma performansı ilgili anket sorularının ortalamaları alınarak elde edilmiştir. Bu tabloda $0.088^{\prime}$ den büyük korelasyon değerleri \%5 derecesinde, 0.0154 'ten büyük değerler ise \%1 derecesinde anlamlıdır. Son olarak, tüm değişkenlerin çıkarılan ortalama varyanslarının karekökü (Tablo 3'ün köşegeninde bildirilmiştir), bu değişkenlerin diğer değişkenlerle olan korelasyonundan daha büyük olduğu için, ayırt edici geçerlilik de elde edilmiştir (Fornell ve Larcker, 1981).

Tablo 3: Korelasyon Analizi

\begin{tabular}{lcccccccc}
\hline & $(1)$ & $(2)$ & $(3)$ & $(4)$ & $(5)$ & $(6)$ & $(7)$ & (8) \\
\hline (1) Maliyet önceliği & $\mathbf{0 . 7 7}$ & & & & & & & \\
(2) Kalite önceliği & 0.31 & $\mathbf{0 . 8 2}$ & & & & & & \\
(3) Teslimat önceliği & 0.37 & 0.39 & $\mathbf{0 . 8 0}$ & & & & & \\
(4) Esneklik önceliği & 0.41 & 0.17 & 0.37 & $\mathbf{0 . 7 0}$ & & & & \\
(5) Çevre önceliği & 0.17 & 0.27 & 0.25 & 0.07 & $\mathbf{0 . 8 5}$ & & & \\
(6) Kaçınma odağ1 & 0.16 & 0.10 & 0.16 & 0.17 & 0.05 & $\mathbf{0 . 6 8}$ & & \\
(7) Yönelim odağ1 & 0.17 & 0.16 & 0.17 & 0.10 & 0.09 & 0.62 & $\mathbf{0 . 6 9}$ & \\
(8) Firma performansı & -0.01 & 0.22 & 0.25 & 0.07 & 0.04 & 0.01 & 0.01 & $\mathbf{0 . 7 2}$ \\
\hline
\end{tabular}

Not: $0.088^{\prime}$ den büyük korelasyon değerleri için $p>0.05 ; 0.154^{\prime}$ ten büyük korelasyon değerleri için $p>0.01$.

Ortak yöntem yanlılığını değerlendirmek için, Harman'ın (1967) tek faktör yöntemi ile açıklayıcı faktör analizi yapılmıştır. Sonuçlar, toplam varyansın yalnızca \%20,3'ünün ilk faktör tarafından, toplamda ise \%64,2'sinin sekiz faktör tarafından açıklandığını gösterdiği için ortak yöntem yanlılığı riski bulunmamıştır.

\section{Analitik yaklaşım}

Bu çalışmada, operasyon stratejilerini sınıflandırmak için kümeleme analizi tekniği kullanılmıştır. Kümeleme değişkenleri her biri üçer anket sorusu ile ölçümlenen maliyet, kalite, teslimat, esneklik ve çevrecilik rekabet öncelikleridir. Ölçek güvenilirliği ve geçerliliği Tablo 2'de gösterilen bu öncelikler, üç anket sorusunun ortalaması alınarak elde edilmiştir. Kümeleme analizinde K-means yöntemi, verilerdeki gerçek farklılık yerine cevap yanlılı̆̆ını (evet-eğilimliler, hayır-eğilimliler) gruplayan sonuçlar verdiği için giderek daha fazla eleştirilmektedir (van Rosmalen, van Herk ve Groenen, 2010). $\mathrm{Bu}$ nedenle, hiyerarşik kümeleme analizi yöntemi tercih edilmiştir. Kümeler MATLAB yazılımı kullanılarak ve kümeler arası farklılık Mahalanobis mesafesi ve tam bağlantı yöntemi ile hesaplanarak belirlenmiştir (Hair, Black, Babin ve Anderson., 2010). İlk olarak, ortaya çıan kümeler için kümeleme değişkenlerinin düzeyleri ve bu değişkenler arasındaki anlamlı farklar değerlendirilerek kümeler isimlendirilmiştir. Sonrasında ise, kümeler arasındaki CEO baskın düzenleme odağı ve performans 
farkları ANOVA testi ile analiz edilmiştir. Çalışmada uygulanan akademik yaklaşımın adımları Şekil $3^{\prime}$ de gösterilmiştir.

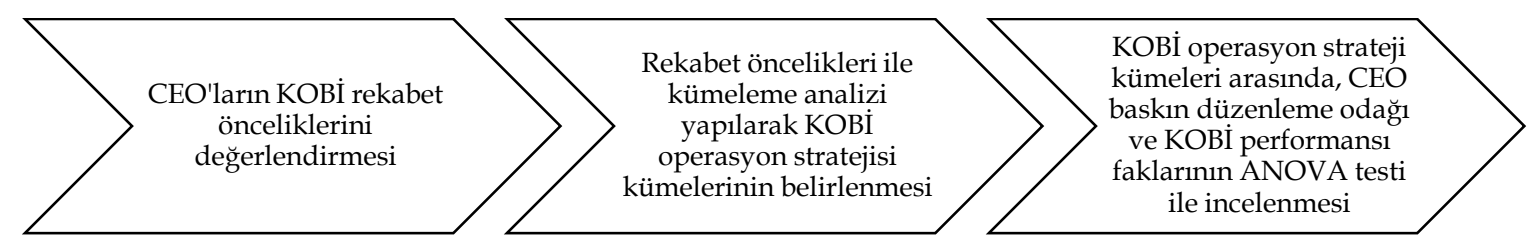

Şekil 3: Çalışmada Uygulanan Analitik Yaklaşımın Adımları

\section{Bulgular}

Hollanda bahçecilik endüstrisinde faaliyet gösteren 629 firma, maliyet, kalite, teslimat, esneklik ve çevrecilik rekabetçi önceliklerine göre kümeleme analizi ile sınıflandırıldığında, dört ana operasyon strateji kümesinden oluşan taksonomi, istatistiksel ve kavramsal olarak en anlamlı sonucu vermiştir. Kümeleme analizinin sonuçları Tablo 4'te verilmiştir. Bu tabloda, her bir kümeleme değişkeni (maliyet, kalite, teslimat, esneklik ve çevrecilik rekabet öncelikleri) için iki satır ayrılmışır. İlk satırda her kümedeki KOBI'lerin rekabet önceliklerindeki ortalamaları verilmiştir. İkinci satırda ise, kümelerin ilgili rekabet önceliğinde hangi diğer kümelerden anlamlı derecede farklılık gösterdiği parantez içinde listelenmiştir. Firma sayısı son satırda, kümeleme değişkenlerinin kümeleri anlamlı derecede ayırt edip etmediğini gösteren $\mathrm{F}$ testleri ise son sütunda gösterilmiştir. Örnek olarak, küme 1'de yer alan 163 KOBI' nin maliyet rekabet önceliğine verdiği önemin ortalaması 4.08 'dir ve bu küme maliyet rekabet önceliğinde küme 2, 3 ve 4 'den anlamlı derecede farklıllk göstermektedir. ANOVA testindeki $\mathrm{F}$ değerlerine bakıldığında (Scheffe testi sonuçlarına göre), kümeler arası anlamlı ölçüde farklılık olduğu gözlendiği için $(\mathrm{p}<0.001)$ kümeleme analizinin geçerli olduğu sonucuna varılmıştır.

Tablo 4: Kümeleme Analizi Bulguları

\begin{tabular}{lccccc}
\hline $\begin{array}{l}\text { Rekabetçi } \\
\text { öncelikler }\end{array}$ & $\begin{array}{c}\text { Küme 1 - } \\
\text { Gelenekçiler }\end{array}$ & $\begin{array}{c}\text { Küme 2 - } \\
\text { Mükemme- } \\
\text { liyetçiler }\end{array}$ & $\begin{array}{c}\text { Küme 3 - } \\
\text { Niş̧ } \\
\text { oyuncular }\end{array}$ & $\begin{array}{c}\text { Küme 4 - } \\
\text { Odaksızlar }\end{array}$ & F testi \\
\hline Maliyet önceliği & 4.08 & 4.41 & 3.56 & 3.59 & 88.23 \\
Anlamlı Fark & $(2,3,4)$ & $(1,3,4)$ & $(1,2)$ & $(1,2)$ & \\
Kalite önceliği & 4.36 & 4.83 & 4.65 & 3.85 & 156.04 \\
Anlamlı Fark & $(2,3,4)$ & $(1,3,4)$ & $(1,2,4)$ & $(1,2,3)$ & \\
Teslimat önceliği & 4.15 & 4.46 & 3.68 & 3.36 & 139.58 \\
Anlamlı Fark & $(2,3,4)$ & $(1,3,4)$ & $(1,2,4)$ & $(1,2,3)$ & \\
Esneklik önceliği & 3.96 & 3.98 & 2.47 & 3.26 & 224.76 \\
Anlamlı Fark & $(3,4)$ & $(3,4)$ & $(1,2,4)$ & $(1,2,3)$ & \\
Çevrecilik önceliği & 3.06 & 4.19 & 3.61 & 3.45 & 123.77 \\
Anlamlı Fark & $(2,3,4)$ & $(1,3,4)$ & $(1,2)$ & $(1,2)$ & \\
Firma sayısı & $\mathbf{1 6 3}$ & $\mathbf{2 0 2}$ & $\mathbf{1 1 6}$ & $\mathbf{1 4 8}$ & \\
\hline
\end{tabular}

Şekil 4'te, kümeleme analizi ile belirlenen dört operasyon stratejisi kümesindeki KOBI'lerin her bir rekabet önceliğindeki ortalama değerlerinin grafiği çizilmiştir. Bu şekil, sektördeki farklı operasyon strateji konfigürasyonlarını görselleştirmesi konusunda yardımcı olmaktadır. Örnek olarak, ikinci operasyon stratejisi kümesindeki KOBİler (turuncu çizgi) beş rekabet önceliğinin hepsine yüksek vurgu yapmakta, dördüncü operasyon strateji kümesindeki KOBI'ler ise (sarı çizgi) genel olarak hiçbir rekabet önceliğini yüksek değerlendirmemektedirler. Kümeleme analizinin sonuçlarına göre belirlenen dört farklı operasyon stratejisi, sırasıyla "Gelenekçiler", "Mükemmeliyetçiler", "Niş oyuncular" ve "Odaksızlar" olarak isimlendirilmiştir. 


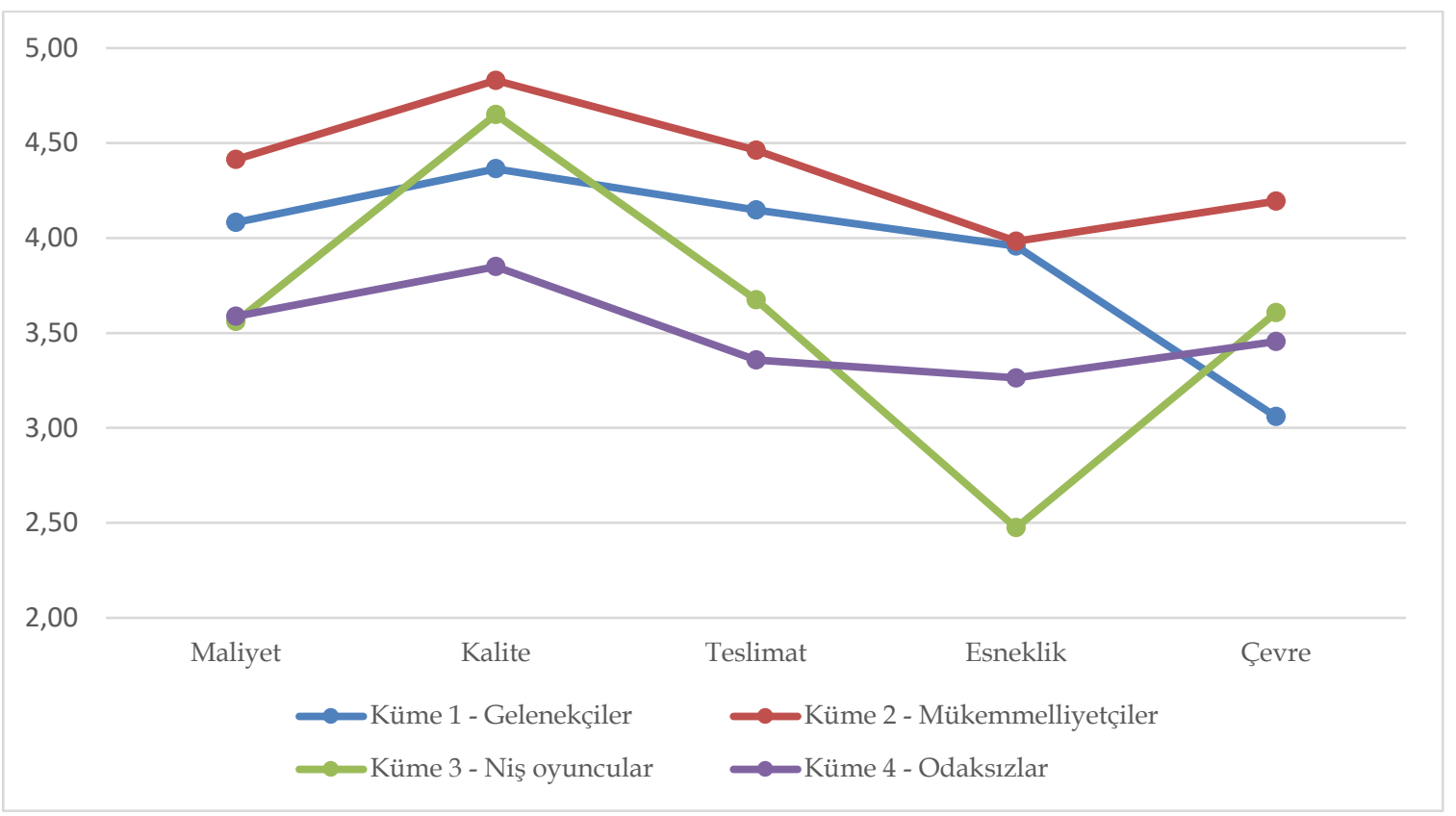

Şekil 4: Hollanda Bahçecilik Endüstrisi Operasyon Stratejileri Taksonomisi

Bu operasyon stratejilerinin özellikleri şu şekildedir:

Küme 1 - Gelenekçiler: Bu küme içerdiği 163 şirket ile en büyük ikinci operasyon stratejisi kümesidir. Bu kümedeki şirketler, ağırlıklı olarak geleneksel rekabetçi önceliklere, yani kalite, maliyet ve teslimata yüksek önem vermektedirler. Esneklik rekabetçi önceliğine de yüksek önem verilmektedir, ancak çevrecilik rekabetçi önceliği en az bu kümede önceliklendirilmektedir.

Küme 2 - Mükemmeliyetçiler: Bu küme 202 şirket ile örneklemdeki en büyük operasyon stratejisi kümesini oluşturmaktadır. Bu kümedeki şirketler tüm rekabetçi önceliklere oldukça yüksek düzeyde vurgu yaparlar. Dolayısıyla bu firmalar tüm önceliklerde mükemmelliği hedeflemektedir denilebilir. Bu kümede hem geleneksel hem de yenilikçi rekabetçi önceliklerine yüksek önem atfedilmektedir.

Küme 3 - Niş oyuncular: Bu kümede 116 şirket bulunmaktadır. Bu kümedeki şirketler en çok kalite ve çevrecilik önceliklerine vurgu yapmaktadırlar. Maliyet ve teslimat öncelikleri orta derecede vurgulanırken, esneklik önceliğine neredeyse hiç önem verilmemektedir. Bu şirketler en yüksek kaliteye (daha pahalı olsa da) odaklanmakta ve üretimlerinin çevresel etkilerini göz önünde bulundurmaktadırlar. Bu konfigürasyon çevre bilinci yüksek olan müşteriler için önemlidir. Dolayısıyla, bu kümedeki şirketler niş bir müşteri segmentini hedeflemektedir denilebilir.

Küme 4 - Odaksızlar: Bu operasyon stratejisi kümesinde 148 şirket bulunmaktadır. Bu kümedeki şirketler tüm rekabetçi önceliklere orta derecede ve benzer önem atfetmektedir. Bu şirketler rekabetçi önceliklere verdikleri önemlerde herhangi bir farklılaşmaya gitmedikleri için, bu şirketlerin açık ve net bir operasyon stratejileri ve stratejik yönelimleri yoktur denilebilir.

Hipotez 1 ve 2'yi test etmek için, CEO Düzenleme odağının KOBİ operasyon stratejilerine göre farklılaşıp farklılaşmadığına ANOVA testi ile bakılmıştır. Bu testin sonuçları Tablo 5'te sunulmaktadır. CEO düzenleme odağı değişkeninin, Scheffe testine göre kümeler arasında istatistiksel olarak anlamlı düzeyde farklı olduğu gözlemlenmiştir. Test sonuçlarına göre, "Mükemmeliyetçiler" ve "Niş Oyuncular" kümelerinde, diğer kümelere kıyasla baskın olarak yönelimci odak eğilimi gözlemlenirken, "Gelenekçiler" kümesinde diğer kümelere kıyasla baskın olarak kaçınmacı odak eğilimi bulunmuştur. "Odaksızlar" kümesinde ise baskın bir odak eğilimi gözlemlenmemiştir. Bu sonuçlar Hipotez 1 ve 2'yi destekler niteliktedir, çünkü kaçınma odaklı CEO'lar geleneksel rekabet önceliklerinin ön plana çıktığ1 'Gelenekçiler' operasyon stratejisini seçerken, yönelim odaklı CEO'lar daha yenilikçi rekabet önceliklerinin ön plana çıktığı 'Niş Oyuncular' operasyon stratejisini seçmişlerdir. Aynı zamanda 'Mükemmeliyetçiler' operasyon stratejisi de yenilikçi rekabet öncelikleri olarak nitelendirilen çevrecilik ve esnekliğe vurgu yapmaktadır ve bu kümedeki CEO'ların da baskın düzenleme odağı yönelim odağıdır.

Hipotez 3'ü test etmek için, operasyon stratejilerinin firma performansı açısından farklılık gösterip göstermediği de ANOVA testi ile incelenmiştir. Bu test sonucunda, firma performansının da Scheffe testine göre kümeler arasında istatistiksel olarak anlamlı düzeyde farklı olduğu gözlemlenmiştir. En düşük firma performansının "Odaksızlar" kümesinde olduğu ve bu kümedeki firma performansının 
diğer üç kümeden istatistiksel olarak anlamlı düzeyde düşük olduğu bulunmuştur. Ancak, diğer üç kümedeki firma performansı ise benzer düzeyde çıkmıştır. Bu sonuç, literatürdeki farklı strateji benimseyen firmaların benzer performans gösterebileceklerini ileri süren performans eşliği (ing. 'performance equifinality') görüşüyle uyum göstermektedir (Payne, 2006; Marlin, Ketchen ve Lamont, 2007).

Tablo 5: Kümelemer Arası Düzenleme Odağı ve Firma Performansı Farkları

\begin{tabular}{lccccc}
\hline Değişkenler & $\begin{array}{c}\text { Küme 1 - } \\
\text { Gelenekçiler }\end{array}$ & $\begin{array}{c}\text { Küme 2 - } \\
\text { Mükemme- } \\
\text { liyetçiler }\end{array}$ & $\begin{array}{c}\text { Küme 3 - } \\
\text { Niş̧ } \\
\text { oyuncular }\end{array}$ & $\begin{array}{c}\text { Küme 4 - } \\
\text { Odaksızlar }\end{array}$ & $\begin{array}{c}\mathbf{F} \\
\text { testi }\end{array}$ \\
\hline Düzenleme odağ1 & -0.14 & 0.13 & 0.20 & 0.04 & 12.35 \\
Anlamlı Fark & $(2,3,4)$ & $(1,4)$ & $(1,4)$ & $(1,2,3)$ & \\
Firma performansı & 3.30 & 3.34 & 3.25 & 3.04 & 6.65 \\
Anlamlı Fark & $(4)$ & $(4)$ & $(4)$ & $(1,2,3)$ & \\
Firma sayısı & $\mathbf{1 6 3}$ & $\mathbf{2 0 2}$ & $\mathbf{1 1 6}$ & $\mathbf{1 4 8}$ & \\
\hline
\end{tabular}

\section{Tartışma ve sonuç}

$\mathrm{Bu}$ araştırma, Hollanda bahçecilik endüstrisindeki bitki ve çiçek yetiştiricisi KOBİlerin operasyon stratejileri ile CEO düzenleme odağı arasındaki ilişkiyi incelemiştir. Maliyet, kalite, teslimat, esneklik ve çevrecilik rekabet önceliklerine verdikleri öneme göre KOBİ'ler operasyon stratejisi kümelerine ayrılmışlar ve bu kümeler arasındaki farklılıklar incelenmiştir. Ortaya çıkan dört küme, önceki çalışmalarda bulunan operasyon stratejisi taksonomileri ile uyumludur. Mükemmeliyetçiler Kathuria (2000) ve Martín-Peña ve Díaz-Garrido'nun (2008) çalışmalarında, odaksızlar Frohlich ve Dixon (2001) ve Sum, Low ve Chen'in (2004) çalışmalarında, gelenekçiler Christiansen ve diğerlerinin (2003) çalışmasında ve niş oyuncular Christiansen ve diğerleri (2003), Kathuria (2000), Frohlich ve Dixon (2011) ve Miller ve Roth'un (1994) çalışmalarında karşımıza çıkmaktadır.

$\mathrm{Bu}$ operasyon stratejisi kümeleri arasında CEO düzenleme odağı farkları test edildiğinde edinilen bulgular, yönelim odağı baskın olan CEO'ların, çevre ve esneklik rekabet öncelikleri gibi daha yenilikçi önceliklere vurgu yapan operasyon stratejilerini, kaçınma odağı baskın olan CEO'ların ise, maliyet, kalite, teslimat gibi daha geleneksel önceliklere vurgu yapan operasyon stratejilerini seçtiklerini göstermiştir. Operasyon strateji kümeleri arasında organizasyonel performans açısından belirgin bir fark gözlemlenmemiş, sadece hiçbir rekabet önceliğine fazla vurgu yapmayan "Odaksızlar" kümesinin performansının diğer kümelerden düşük olduğu bulunmuştur.

CEO'ların yönelim düzenleme odağının baskın olması, yönettikleri KOBI'lerin gelecekte olabilecekleri ideal durumlara erişebilmelerine odaklandıklarını, bu doğrultuda risk alabildiklerini ve yeni görüşlere açık olduklarını ifade eder. Aynı zamanda, yönelim düzenleme odağına sahip CEO'lar başarıya ulaşmak için birden fazla yolu ve mekanizmayı denemekten çekinmezler (Wallace ve diğerleri, 2010). $\mathrm{Bu}$ araştırmanın bulguları, kalite ve çevrecilik rekabet önceliklerine vurgu yapan 'Niş oyuncular' operasyon stratejisi ve geleneksel rekabet öncelikleri kadar esneklik ve çevrecilik gibi yenilikçi öncelikleri de vurgulayan 'Mükemmeliyetçiler' operasyon stratejisinin baskın düzenleme odağ1 yönelim olan CEO'lar tarafından anlamlı düzeyde daha fazla tercih edildiğini göstermektedir.

Kayıpları en aza indirme ve korumacı bir güvenlik anlayışıyla hareket eden, kaçınma odağı baskın olan CEO'lar ise hata yapmamak için daha genel geçer ve güvenilirliği test edilmiş olan geleneksel rekabetçi önceliklere vurgu yapan operasyon stratejilerini tercih ederler. Bu çalışma, maliyet, kalite ve teslimat rekabetçi önceliklerine diğerler önceliklerden daha fazla vurgu yapan 'Gelenekçiler' operasyon stratejisini benimseyen CEO'ların baskın düzenleme odağının kaçınma olduğunu ortaya koymaktadır.

Operasyon strateji kümeleri arasında, firma performansı açısından 'Odaksızlar' hariç bir fark bulunamaması, organizasyonların aynı etkinliğe sahip farklı operasyon stratejileri takip edebileceklerini göstermektedir (Drazin ve van de Ven, 1985; Bozarth ve McDermott, 1998). Gelecekteki çalışmalar operasyon strateji kümeleri içinde düzenleyici ve aracı değişkenleri çalışarak, bu stratejilerin ne zaman ve nasıl performans farkı gösterebileceklerini inceleyebilirler.

Bu çalışmanın bulguları hem davranışsal strateji hem de operasyon yönetimi literatürüne anlamlı teorik ve pratik katkılar yapmaktadır. Strateji literatüründe CEO'ların kurum performansına etkisi uzun süredir araştırılan bir konudur. CEO'ların ve diğer üst düzey yöneticilerin bilişsel yetkinliklerinin ve değerlerinin stratejik kararlar, kurum çıktıları ve performansına olası etkisi hakkında kuramsal bir 
çerçeve sunan üst kademeler teorisinin (Hambrick ve Mason 1984) önerilmesinden sonra, pek çok araştırmacı CEO'ların demografik özellikleri ve psikolojik karakteristikleri hakkında ampirik çalışmalar ortaya koymuşlardır. Bu çalışmalardan CEO düzenleme odağına yoğunlaşan anlamlı sayıda çalışma vardır. Ancak bu makalelerin büyük kısmı büyük ve orta ölçekli işletmeler bağlamında CEO düzenleme odağını incelemektedir. Bu çalışma, CEO baskın düzenleme odağının operasyon stratejisi seçimine olan etkisini KOBI’ler bağlamında göstererek, özellikle davranışsal strateji literatürüne önemli bir katkıda bulunmaktadır.

Bu çalışma aynı zamanda operasyon yönetimi alanına katkı sunmaktadır. Operasyon yönetimi literatüründe rekabetçi öncelikle ve operasyon stratejileri çalışmaları genellikle CEO'ları kişilikleri ile ilgili değişkenlere, özellikle düzenleme odağı gibi CEO karar ve davranışları altında yatan güdüleri açıklayan bir kavrama, birkaç istisna dışında (Phadnis ve diğerleri, 2017; Gamache ve diğerleri, 2020) odaklanmamışlardır. Operasyon stratejileri rekabet stratejilerinin bütünleşik bir parçası olması itibariyle şirketlerin performansı ve hayatta kalabilmeleri için çok önemlidir. Bu stratejilerin belirlenmesindeki en önemli karar verici aktörlerin başında gelen CEO'lara tuttuğu ışık ile, bu çalışma operasyon stratejilerinin yeni davranışsal öncüllerini bularak literatüre katkıda bulunmaktadır.

Yöneticilerin kendi baskın düzenleme odaklarının (kaçınma ya da yönelim odağı) farkında olmaları, onları daha önce değerlendirmedikleri operasyon stratejilerinin potansiyel faydalarını da düşünmeye sevk edebilir. Kaçınma odağı baskın olan yöneticilerin yenilikçi rekabet önceliklerine de vurgu yapan stratejileri değerlendirmeleri ve yönelme odağı baskın olan yöneticilerin ise geleneksel rekabet önceliklerine de vurgu yapan stratejileri göz önünde bulundurmaları KOBİlerin stratejik alternatiflerinin genişletecektir. KOBI'ler için yüksek performansa yol açan tek bir operasyon stratejisinin olmaması, yani birbirinden farklı operasyon stratejileriyle benzer firma performaslarına erişilebilmesi de farklı stratejilerin değerlendirilmesinin önemine işaret etmektedir. Dolayısıyla, operasyon stratejisi, maliyet, kalite, teslimat, esneklik ve çevrecilik rekabet önceliklerine verilen önemin konfigürasyonu olduğu için geleneksel ve yenilikçi önceliklerin faklı kombinasyonlarının benimsenmesi KOBİ'ler için eşsiz olanaklar barındırabilir.

Her çalışmanın olduğu gibi bu çalışmanın da bazı kısıtları mevcuttur. İlk olarak, çalışma enine kesit bir çalışma olduğu için nedensellik ve ilişkilerin yönü ile ilgili nihai yorumlar yapılamamaktadır. Gelecek araştırmalar, farklı zaman dilimlerinde veri toplanan boylamsal bir çalışma tercih edebilirler. İkinci bir kısıt, çalışmanın her ne kadar yüksek bir örneklem büyüklüğü ile yapılsa ve istatistiksel kontroller yeterli düzeyde olsa da tüm soruları Likert tipi göstergelerle toplaması bir kısıttır. İlerideki çalışmalar ortak yöntem yanlılığı riskini en aza indirecek, farklı metotları bir arada kullanan çalışmalar yapabilir. Ayn zamanda, araştırmacılar ileride CEO narsiszmi (Cragun Olsen ve Wright, 2020), üst düzey özgüveni (Billett ve Qian, 2008) veya politik ideolojisi (Park, Boeker ve Gomulya, 2020) gibi farklı CEO özelliklerinin, KOBİ operasyon stratejileri ve firma performansı ilişkisinde nasıl roller oynadıklarını inceleyebilirler. Bu süreçteki aracı ve düzenleyici değişkenlerin de daha fazla araştırılmasına ihtiyaç vardir.

Bu çalışmanın bulguları operasyon stratejilerinden çoğu zaman doğrudan sorumlu olan üretim yöneticilerine, iki temel mesaj vermektedir. İlk olarak, yöneticiler kendi düzenleme odaklarının farkında olmalı ve verecekleri stratejik kararlarını etkileme potansiyeline sahip örtülü değişkenler hakkında bilgi sahibi olmalılardır. Baskın düzenleme odağı hakkında bilinçli kişiler, üst yönetim ekiplerine farklı düzenleme odaklarına sahip kişileri yükseltme için tercih edebilirler. İkinci olarak, organizasyonlar için başarılı olunacak tek bir yol yoktur. Benzer performanslara sebebiyet verecek pek çok farklı etmen vardır.

\section{Hakem Değerlendirmesi / Peer-review:}

Dış bağımsız

Externally peer-reviewed

\section{Çıkar Çatışması / Conflict of interests:}

Yazar(lar) çıkar çatışması bildirmemiştir.

The author(s) has (have) no conflict of interest to declare. 


\section{Finansal Destek / Grant Support:}

Yazarlar bu çalışma için finansal destek almadığını beyan etmiştir.

The authors declared that this study has received no financial support.

\section{Yazar Katkıları / Author Contributions:}

Fikir/Kavram/Tasarım - Idea/Concept/ Design: N.Y.A., M.A.A. Veri Toplama ve/veya İşleme - Data Collection and/or Processing: N.Y.A., M.A.A. Analiz ve/veya Yorum - Analysis and/or Interpretation: N.Y.A., M.A.A. Kaynak Taramas1 - Literature Review: N.Y.A., M.A.A., Makalenin Yazımı - Writing the Article: N.Y.A., M.A.A. Eleştirel İnceleme - Critical Review: N.Y.A., M.A.A. Onay - Approval: N.Y.A., M.A.A.

\section{Kaynakça / References}

Anderson, J. C., \& Gerbing, D. W. (1988). Structural equation modeling in practice: A review and recommended two-step approach. Psychological Bulletin, 103(3), 411-423.

Ateş, M.A., Wynstra, F., \& van Raaij, E. M. (2021). Developing a purchasing strategy taxonomy based on competitive priorities. Hacettepe Üniversitesi İktisadi ve İdari Bilimler Fakültesi Dergisi, 39(1), 33-49.

Bagozzi, R. P., Yi, Y., \& Phillips, L. W. (1991). Assessing construct validity in organizational research, Administrative Science Quarterly, 36(3), 421-458.

Bierly III, P. E., \& Daly, P. S. (2007). Alternative knowledge strategies, competitive environment, and organizational performance in small manufacturing firms. Entrepreneurship Theory and Practice, 31(4), 493-516.

Billett, M. T., \& Qian, Y. (2008). Are overconfident CEOs born or made? Evidence of self-attribution bias from frequent acquirers. Management Science, 54(6), 1037-1051.

Boyer, K. K., \& Lewis, M. W. (2002). Competitive priorities: investigating the need for trade-offs in operations strategy. Production and Operations Management, 11(1), 9-20.

Bozarth, C., \& McDermott, C. (1998). Configurations in manufacturing strategy: a review and directions for future research. Journal of Operations Management, 16(4), 427-439.

Brockner, J., Higgins, E. T., \& Low, M. B. (2004). Regulatory focus theory and the entrepreneurial process. Journal of Business Venturing, 19(2), 203-220.

Cannella Jr, A. A., Park, J. H., \& Lee, H. U. (2008). Top management team functional background diversity and firm performance: Examining the roles of team member colocation and environmental uncertainty. Academy of Management Journal, 51(4), 768-784.

Carpenter, M. A., Geletkanycz, M. A., \& Sanders, W. G. (2004). Upper echelons research revisited: antecedents, elements, and consequences of top management team composition. Journal of Management, 30(6), 749-778.

Carpinetti, L. C., Gerolamo, M. C., \& Dorta, M. (2000). A conceptual framework for deployment of strategy-related continuous improvements. The TQM Magazine, 12(5), 340-349.

Christiansen, T., Berry, W. L., Bruun, P., \& Ward, P. (2003). A mapping of competitive priorities, manufacturing practices, and operational performance in groups of Danish manufacturing companies. International Journal of Operations \& Production Management, 23(10), 1163-1183.

Cragun, O. R., Olsen, K. J., \& Wright, P. M. (2020). Making CEO narcissism research great: A review and meta-analysis of CEO narcissism. Journal of Management, 46(6), 908-936.

Crowe, E., \& Higgins, E. T. (1997). Regulatory focus and strategic inclinations: promotion and prevention in decision-making. Organizational Behavior and Human Decision Processes, 69(2), 117-132.

De Vries, J., De Koster, R., \& Stam, D. (2016). Aligning order picking methods, incentive systems, and regulatory focus to increase performance. Production and Operations Management, 25(8), 1363-1376. 
Drazin, R., \& van de Ven, A. H. (1985). Alternative forms of fit in contingency theory. Administrative Science Quarterly, 514-539.

Finkelstein, S., \& Hambrick, D. (1990). Top-management-team tenure and organizational outcomes: the moderating role of managerial discretion. Administrative Science Quarterly, 35(3), 484-503.

Fornell, C., \& Larcker, D. F. (1981). Evaluating structural equation models with unobservable variables and measurement error. Journal of Marketing Research, 18(1), 39-50.

Fredrickson, J. W., \& Mitchell, T. R. (1984). Strategic decision processes: Comprehensiveness and performance in an industry with an unstable environment. Academy of Management Journal, 27(2), $399-423$.

Frohlich, M. T., \& Dixon, J. R. (2001). A taxonomy of manufacturing strategies revisited. Journal of Operations Management, 19(5), 541-558.

Gamache, D. L., McNamara, G., Mannor, M. J., \& Johnson, R. E. (2015). Motivated to acquire? The impact of CEO regulatory focus on firm acquisitions. Academy of Management Journal, 58(4), 1261-1282.

Gamache, D.L., Neville, F., Bundy, J., \& Short, C. E. (2020). Serving differently: CEO regulatory focus and firm stakeholder strategy. Strategic Management Journal, 41(7), 1305-1335.

Gelhard, C., von Delft, S., \& Gudergan, S. P. (2016). Heterogeneity in dynamic capability configurations: Equifinality and strategic performance. Journal of Business Research, 69(11), 5272-5279.

Hair, J., Black, W., Babin, B., Anderson, R. (2010). Multivariate Data Analysis: A Global Perspective, New Jersey: Pearson.

Hambrick, D. (2007). Upper echelons theory: An update. Academy of Management Review, 32(2), 334-343.

Hambrick, D., \& Fukutomi, G. (1991). The seasons of a CEO's tenure. Academy of Management Review, $16,719-742$.

Hambrick, D. \& Mason, P.A. (1984). Upper echelons: the organization as a reflection of its top managers. Academy of Management Review, 9(2), 193-206.

Harman, H. (1967), Modern Factor Analysis, Chicago: University of Chicago Press.

Hayes, R. H., \& Wheelwright, S.C. (1984). Restoring Our Competitive Edge: Competing Through Manufacturing, New York: Wiley.

Higgins, E. T. (1997). Beyond pleasure and pain. American Psychologist, 52(12), 1280-1300.

Higgins, E. T. (1998). Promotion and prevention: Regulatory focus as a motivational principle. Advances in Experimental Social Psychology, 30, 1-46.

Higgins, E. T., Friedman, R. S., Harlow, R .E., Idson, L. C., Ayduk, O. N., \& Taylor, A. (2001). Achievement orientations from subjective histories of success: promotion pride versus prevention pride. European Journal of Social Psychology, 31(1), 3-23.

Higgins, E. T., \& Silberman, I. (1998). Development of regulatory focus: promotion and prevention as ways of living. In: Heckhausen, J., Dweck, C. S. (Eds.), Motivation and Self-regulation Across the Life Span. Cambridge University Press, New York, 78-113.

Hmieleski, K. M., \& Baron, R. A. (2008). Regulatory focus and new venture performance: A study of entrepreneurial opportunity exploitation under conditions of risk versus uncertainty. Strategic Entrepreneurship Journal, 2(4), 285-299.

Idson, L. C., Liberman, N., \& Higgins, E. T. (2000). Distinguishing gains from non-losses and losses from non-gains: a regulatory focus perspective on hedonic intensity. Journal of Experimental Social Psychology, 36(3), 252-274.

Kammerlander, N., Burger, D., Fust, A., \& Fueglistaller, U. (2015). Exploration and exploitation in established small and medium-sized enterprises: The effect of CEOs' regulatory focus. Journal of Business Venturing, 30(4), 582-602.

Kashmiri, S., Gala, P., \& Nicol, C. D. (2019). Seeking pleasure or avoiding pain: Influence of CEO regulatory focus on firms' advertising, R\&D, and marketing controversies. Journal of Business Research, 105, 227-242.

Kathuria, R. (2000). Competitive priorities and managerial performance: a taxonomy of small manufacturers. Journal of Operations Management, 18(6), 627-641. 
Kathuria, R., Kathuria, N. N., Kathuria, A. (2018). Mutually supportive or trade-offs: an analysis of competitive priorities in the emerging economy of India. The Journal of High Technology Management Research, 29(2), 227-236.

Kathuria, R., Partovi, F. Y., \& Greenhaus, J. H. (2010). Leadership practices, competitive priorities, and manufacturing group performance. International Journal of Operations \& Production Management, 30(10), 1080-1105.

Kathuria, R., Porth, S. J., \& Joshi, M. P. (1999). Manufacturing priorities: do general managers and manufacturing managers agree? International Journal of Production Research, 37(9), 2077-2092.

Kim, J. S., \& Arnold, P. (1996). Operationalizing manufacturing strategy: an exploratory study of constructs and linkage. International Journal of Operations \& Production Management, 16(12), 45-73.

Lanaj, K., Chang, C. H., \& Johnson, R. E. (2012). Regulatory focus and work-related outcomes: a review and meta-analysis. Psychological Bulletin, 138(5), 998-1034.

Lockwood, P., Jordan, C. H., \& Kunda, Z. (2002). Motivation by positive or negative role models: Regulatory focus determines who will best inspire us. Journal of Personality and Social Psychology, 83(4), 854.

Lubatkin, M., Simsek, Z., \& Veiga, J. (2006). Ambidexterity and performance in small-to medium-sized firms: the pivotal role of top management team behavioral integration. Journal of Management, 32(5), 646-672.

Marlin, D., Ketchen Jr, D. J., \& Lamont, B. (2007). Equifinality and the strategic groups - performance relationship. Journal of Managerial Issues, 208-232.

Martín-Peña, M.L., \& Díaz-Garrido, E. (2008). A taxonomy of manufacturing strategies in Spanish companies. International Journal of Operations \& Production Management, 28(5), 455-477.

Miller, J. G., \& Roth, A.V. (1994). A taxonomy of manufacturing strategies. Management Science, 40(3), 285-304.

Nadkarni, S., \& Herrmann, P. O. L. (2010). CEO personality, strategic flexibility, and firm performance: The case of the Indian business process outsourcing industry. Academy of Management Journal, 53(5), 1050-1073.

Park, U. D., Boeker, W., \& Gomulya, D. (2020). Political ideology of the board and CEO dismissal following financial misconduct. Strategic Management Journal, 41(1), 108-123.

Payne, G. T. (2006). Examining configurations and firm performance in a suboptimal equifinality context. Organization Science, 17(6), 756-770.

Peng, D. X., Schroeder, R. G., \& Shah, R. (2011). Competitive priorities, plant improvement and innovation capabilities, and operational performance: A test of two forms of fit. International Journal of Operations \& Production Management, 31(5), 484-510.

Phadnis, S. S., Sheffi, Y., Caplice, C., \& Singh, M. (2017). Strategic cognition of operations executives. Production and Operations Management, 26(12), 2323-2337.

Phusavat, K., \& Kanchana, R. (2007). Competitive priorities of manufacturing firms in Thailand. Industrial Management \& Data Systems, 107(7), 979-996.

Porter, M. E. (1997). Competitive strategy. Measuring Business Excellence, 1(2), 12-17.

Powell, T. C., Lovallo, D., \& Fox, C. R. (2011). Behavioral strategy. Strategic Management Journal, 32(13), 1369-1386.

Raisch, S., \& Birkinshaw, J. (2008). Organizational ambidexterity: Antecedents, outcomes, and moderators. Journal of Management, 34(3), 375-409.

Shah, J., \& Higgins, E. T. (2001). Regulatory concerns and appraisal efficiency: the general impact of promotion and prevention. Journal of Personality and Social Psychology, 80(5), 693.

Sum, C. C., Low, L. S., \& Chen, C. S. (2004). A taxonomy of operations strategies of high performing small and medium enterprises in Singapore. International Journal of Operations and Production Management, 24 (3), 321-345.

Tang, Y., Mack, D. Z., \& Chen, G. (2018). The differential effects of CEO narcissism and hubris on corporate social responsibility. Strategic Management Journal, 39(5), 1370-1387. 
Tumasjan, A., \& Braun, R. (2012). In the eye of the beholder: How regulatory focus and self-efficacy interact in influencing opportunity recognition. Journal of Business Venturing, 27(6), 622-636.

Vachon, S., Halley, A., \& Beaulieu, M. (2009). Aligning competitive priorities in the supply chain: the role of interactions with suppliers. International Journal of Operations \& Production Management, 29(4), 322-340.

van Rosmalen, J., van Herk, H., Groenen, P. J. F. (2010). Identifying response styles: a latent-class bilinear multinomial logit model. Journal of Marketing Research, 47(1), 157-172.

Venkatraman, N., \& Ramanujam, V. (1987). Measurement of business economic performance: an examination of method convergence. Journal of Management, 13(1), 109-122.

Wallace, J. C., Johnson, P. D., \& Frazier, M. L. (2009). An examination of the factorial, construct, and predictive validity and utility of the regulatory focus at work scale. Journal of Organizational Behavior, 30(6), 805-831.

Wallace, J. C., Little, L. M., Hill, A. D., \& Ridge, J. W. (2010). CEO regulatory foci, environmental dynamism, and small firm performance. Journal of Small Business Management, 48(4), 580-604.

Ward, P. T., McCreery, J. K., Ritzman, L. P., \& Sharma, D. (1998). Competitive priorities in operations management. Decision Sciences, 29(4), 1035-1046.

Wiklund, J., Davidsson, P., \& Delmar, F. (2003). What do they think and feel about growth? An expectancy-value approach to small business managers' attitudes toward growth. Entrepreneurship Theory and Practice, 27(3), 247-270.

Zhao, X., Sum, C. C., Qi, Y., Zhang, H., \& Lee, T. S. (2006). A taxonomy of manufacturing strategies in China. Journal of Operations Management, 24(5), 621-636.

Zhao, X., Yan Yeung, J. H., \& Zhou, Q. (2002). Competitive priorities of enterprises in mainland China. Total Quality Management, 13(3), 285-300.

Zhu, D. H., \& Chen, G. (2015). CEO narcissism and the impact of prior board experience on corporate strategy. Administrative Science Quarterly, 60(1), 31-65. 